\title{
SĄDOWA WERYFIKACJA WYGASZANIA STOSUNKÓW PRACY W SFERZE ADMINISTRACJI PUBLICZNEJ
}

\author{
Abstract \\ Judicial verification of the termination of employment relations in the sphere of public \\ administration on the example of the National Center for Agricultural Support
}

The construction of the expiry of an employment relationship excludes the use of institutions provided for in the Labor Code for the termination of employment relationships, as it is a lex specialis in relation to the provisions of this Code. This mechanism results in the termination of the employment relationship, in principle, without the labor court being able to check the reasons for it. The labor court, in such conditions, may, however, examine not only whether the expiration of the employment contract by the employer did not violate the law, but also, and perhaps above all, the circumstances of not offering the employee working conditions and pay for a further period and assess it also in context of social coexistence rules.

Keywords: expiry of an employment relationship, termination of employment, employment protection, equal treatment in employment

Słowa kluczowe: wygaśnięcie stosunku pracy, rozwiązanie stosunku pracy, ochrona pracy, zasada równego traktowania w zatrudnieniu

ASJC: 3308 , JEL: K31

W niniejszym opracowaniu autorka poddaje analizie konstrukcję prawną wygaśnięcia stosunku pracy, którą posiłkują się przepisy szczególne regulujące warunki pracy w ramach szeroko pojętego aparatu państwowego (publicznego), zwłaszcza w sytuacji likwidacji istniejących struktur i zastępowania ich nowymi, o zasadniczo takich samych lub bardzo zbliżonych zadaniach i kompetencjach. Powyższa kwestia nabrała istotnego znaczenia w kontekście ostatnich zmian dokonanych w sferze administracji publicznej związanych z powołaniem Krajowego Ośrodka Wsparcia Rolnictwa. 


\section{Wprowadzenie}

Stosunek pracy trwa do czasu jego ustania, którego przyczyną może być jego rozwiązanie lub wygaśnięcie. Zgodnie z art. 63 ustawy z dnia 26 czerwca 1974 roku - Kodeks pracy (Dz.U. 2019, poz. 1040 tekst jedn. ze zm., dalej: Kodeks pracy, k.p.) umowa o pracę wygasa w przypadkach określonych w Kodeksie (art. 631 i n. k.p.) oraz w przepisach szczególnych. Przypadki określone w przepisach prawa pracy stanowią katalog zamknięty i uniemożliwiają kontynuowanie zatrudnienia z przyczyn obiektywnych i niezależnych de facto od stron stosunku pracy (por. jednak wyrok Sądu Najwyższego z dnia 7 kwietnia 2010 roku, II UK 357/09, OSNP 2011, nr 19-20, poz. 258). Konstrukcją prawną wygaśnięcia posiłkują się również tak zwane pragmatyki pracownicze (służbowe) regulujące warunki pracy w ramach szeroko pojętego aparatu państwowego (publicznego), gdzie ten tryb ustania stosunku pracy jawi się jako instytucja specyficzna (Jończyk 1984, s. 400; Hofmańska 2015; Stelina 2015, s. 223 i n.; Witoszko 2016, s. 171 i n.).

Wprowadzenie wygaśnięcia stosunków pracy z mocy ustawy jest dopuszczalne, jednakże w sytuacjach szczególnych i uzasadnionych zmianami ustrojowymi państwa. Wspomniany ( $\mathrm{w}$ istocie wyjątkowy) tryb ustania stosunku pracy powinien mieć zatem uzasadnienie nie tylko prawne, ale i aksjologiczne, co wynika również z pewnych następstw zastosowania tej instytucji. Otóż tego rodzaju konstrukcja prawna stanowi odstępstwo od zasady swobody kontraktowej i trwałości zatrudnienia pracowniczego, a ponadto wprowadza konkurencyjny mechanizm względem gwarancji przewidzianych w przepisach o rozwiązywaniu stosunków pracy. Nie jest zatem tak, że skoro ustawodawca przewidział skutek wygaśnięcia stosunku pracy, to kwestia ta jest jednoznaczna, wręcz bezdyskusyjna i nie podlega interpretacji. Takie założenie wprawdzie mieści się w kanonie prawniczym, jednakże z uwagi na zbytni formalizm może prowadzić do niesłusznych wniosków.

\section{Konstrukcja wygaśnięcia stosunku pracy}

Jak już wspomniano, wygaśnięcie stosunku pracy stanowi jeden ze sposobów ustania stosunku pracy. Przepis art. 63 k.p. stanowi, że umowa o pracę wygasa w przypadkach określonych w Kodeksie oraz w przepisach szczególnych. Jako zdarzenia powodujące wygaśnięcie stosunku pracy Kodeks pracy wymienia enumeratywnie: śmierć pracownika (art. 631 k.p.), śmierć pracodawcy - z pewnymi zastrzeżeniami (art. 632 k.p.), niezgłoszenie przez pracownika powrotu do pracy po rozwiązaniu stosunku pracy z wyboru (art. 74 k.p.) i upływ trzymiesięcznego okresu nieobecności pracownika w pracy spowodowanej tymczasowym aresztowaniem (art. $66 \$ 1$ k.p.). Ustalenie katalogu przyczyn wygaśnięcia $\mathrm{w}$ przepisach pozakodeksowych wymaga sięgnięcia do regulacji szczególnych.

Wygaśnięcie z mocy prawa stosunku pracy powoduje, że pracodawca faktycznie nie ma żadnych możliwości korzystania z określonego prawem władztwa, bo żaden zakres 
takiego władztwa nie został w tej instytucji przewidziany. Nie ma więc możliwości ani negatywnego, ani pozytywnego ustosunkowania się do sytuacji prawnych powstałych z mocy samego prawa, nie ma też miejsca - połączona z wyrażeniem woli przez pracodawcę - indywidualizacja i konieczna przy indywidualnych rozstrzygnięciach podwójna konkretyzacja normy prawnej. Skutek ten jest dostrzegalny zwłaszcza w przypadku wygaszania stosunków pracy w sferze administracji publicznej, szczególnie gdy dotyczy on pewnej grupy pracowników, czyli zastosowanie tej instytucji ma charakter „masowy”. $\mathrm{Na}$ tym tle kodeksowe przyczyny wygaśnięcia stosunku pracy, zwłaszcza umownego, jawią się jako niebudzące kontrowersji i niedające pola do nadużyć.

Niezależnie od tego, czy mowa jest o kodeksowych, czy też o pozakodeksowych regulacjach, w przypadku wygaśnięcia stosunku pracy nie znajdują zastosowania takie instytucje prawa pracy jak między innymi:

- przejście zakładu pracy na nowego pracodawcę (art. 231 k.p., zwłaszcza \$6),

- mechanizmy właściwe dla rozwiązywania stosunków pracy (między innymi ochrona ogólna; odnośnie do art. 38 k.p. zob. uzasadnienie wyroku Sądu Najwyższego z dnia 24 maja 2001 roku, I PKN 399/00, OSNP 2003, nr 6, poz. 143; i z reguły procedura doboru pracowników do zwolnienia - w sytuacji redukcji zatrudnienia $\mathrm{z}$ uwagi na brak zapotrzebowania na pracę $\mathrm{w}$ dotychczasowym rozmiarze oraz prawo do odprawy pieniężnej regulowane ustawą z dnia 13 marca 2003 roku o szczególnych zasadach rozwiązywania z pracownikami stosunków pracy z przyczyn niedotyczących pracowników (Dz.U. 2018, poz. 1969 tekst jedn. ze zm., dalej: ustawa z 2003 roku; zob. Dral 2009, s. 249 i n.; Sobczyk 2015, s. 335 i n.).

Odnosząc się do instytucji przejścia zakładu pracy na nowego pracodawcę, która może znaleźć zastosowanie również do zmian organizacyjnych w administracji, czyli w sferze publicznej (Stelina 2015, s. 112), należy wskazać, że jej istotną funkcją jest trwałość stosunku pracy wywodząca się z obowiązku zakładu pracy zatrudnienia pracownika przejmowanego w całości lub w części zakładu pracy (Hajn 1996, s. 17 i n.; Tomanek 2002; Pisarczyk 2007, s. 15; Sanetra 2011, s. 223; por. także uchwałę Sądu Najwyższego z dnia 18 grudnia 2001 roku, III ZP 25/01, OSNP 2002, nr 13, poz. 301 i wyrok Sądu Najwyższego z dnia 27 lipca 2007 roku, I PK 333/06, LEX nr 470022). W konsekwencji, automatyczne wstąpienie pracodawcy przejmującego rolę strony stosunku pracy powoduje stabilizację zatrudnienia, czyli stwarza normatywne podstawy kontynuowania przez pracownika stosunku pracy u nowego pracodawcy (Hajn 1994; Mitrus 1998; Dral 2009, s. 317 i n.). Nieuprawnione zastosowanie mechanizmu wygaszania stosunków pracy wyklucza powyższą ochronę.

Konstrukcja wygaśnięcia stosunku pracy eliminuje również stosowanie instytucji przewidzianych w Kodeksie pracy służących do rozwiązywania stosunków pracy, gdyż stanowi lex specialis w stosunku do przepisów tego Kodeksu (zob. postanowienie Sądu Najwyższego z dnia 4 października 2002 roku, I PK 31/02, LEX nr 1170570). Mechanizm ten powoduje ustanie stosunku pracy w zasadzie bez możliwości kontroli przez sąd pracy przyczyn, dla których to nastąpiło, a zwłaszcza przez pryzmat zasadności decyzji pracodawcy. 
Z instytucją wygaśnięcia stosunku pracy wiążą się zatem dość niekorzystne dla pracownika konsekwencje, których skutkiem jest ograniczona możliwość zakwestionowania prawidłowości jego ustania w trybie typowym dla takich zdarzeń. Ustawodawca zadecydował bowiem, że pewne instytucje - także ochronne - towarzyszące rozwiązywaniu stosunków pracy nie znajdują zastosowania w przypadku jego wygaśnięcia.

\section{Wygaszanie stosunków pracy w kontekście reform administracji publicznej}

Obok przyczyn kodeksowych wygaśnięcia stosunku pracy mogą zaistnieć inne ustawowo uregulowane przyczyny wygaszania stosunków pracy, które z reguły są powiązane ze zmianami organizacyjnymi w sferze administracji publicznej. Dotychczas sytuacja, w której stosunki pracy wygasały z mocy prawa przy reorganizacji podmiotów sektora publicznego, miała miejsce głównie podczas przemian ustrojowych, czyli gruntownych zmian organizacyjnych o doniosłym znaczeniu społecznym (tak zwana prawna regulacja następstw reorganizacji dla stosunków pracy). Wystarczy przywołać w tym względzie między innymi ustawę Przepisy wprowadzające ustawy reformujące administrację publiczną z dnia 13 października 1998 roku (Dz.U. 1998, nr 133, poz. 872). W wyroku z dnia 27 stycznia 2004 roku (I PK 244/03, LEX nr 2449630) Sąd Najwyższy zajął stanowisko, że art. 58 ust. 1 wymienionej ustawy jest tak skonstruowany, że dla pracowników dotychczasowych urzędów wojewódzkich nie zawiera gwarancji zatrudnienia po określonej dacie, a niezłożenie propozycji dalszego zatrudnienia nie podlega co do zasady kontroli sądu. Niezależnie od oceny pozaprawnej przyjętego rozwiązania ustawowego podzielić trzeba pogląd, że ustawodawca przyznał pracodawcom pełną swobodę decydowania o zatrudnieniu pracowników administracji publicznej. Z kolei w przytaczanym wyroku Sądu Najwyższego z dnia 24 maja 2001 roku wyrażono zapatrywanie, że pracodawca nie ma ustawowego obowiązku złożenia pracownikowi, o którym mowa w art. 58 ust. 1 wyżej wymienionej ustawy, propozycji dalszego zatrudnienia, a przewidziana w tym przepisie możliwość zaproponowania „nowych warunków pracy i płacy na dalszy okres" oznacza dopuszczalność innego ukształtowania statusu pracownika. Analogiczne rozwiązanie przewidywała również ustawa z dnia 22 marca 1990 roku o pracownikach samorządowych (Dz.U. 2001, nr 142, poz. 1593 tekst jedn. ze zm.).

Powyższa - z konieczności nieco wybiórcza - analiza prowadzi do wniosku, że wygaszanie stosunków pracy, jakie miały miejsce w latach 1990 i 1998, uzasadniały istotne zmiany ustrojowe: reaktywacja samorządu terytorialnego na szczeblu gmin, a następnie wprowadzenie trójstopniowego podziału terytorialnego kraju oraz samorządu terytorialnego na każdym z tych szczebli. Reforma ustroju państwa, w tym ustroju administracji publicznej, dotyczyła samych fundamentów ładu publicznego w państwie. W takim przypadku istniały wystarczająco silne argumenty przemawiające za odstąpieniem od zasady stabilności i pewności prawa. Taka - istotna - zmiana warunków społecznych lub gospodarczych może wymagać zmian regulacji prawnych, w tym 
tych, które dotyczą nawiązywania i rozwiązywania stosunków pracy. W związku z powyższym w takich uwarunkowaniach instytucja wygaszania stosunków pracy znajduje uzasadnienie prawne oraz wymaganą akceptację, posiadając właściwą podbudowę aksjologiczną. Nie jawi się jako instytucja służąca jedynie arbitralnemu pozbawianiu zatrudnienia. Na takim stanowisku stanął zresztą Trybunał Konstytucyjny w wyroku z dnia 13 marca 2000 roku (K 1/99, OTK 2000, nr 2, poz. 59), podkreślając potrzebę ochrony innych wartości i zasad konstytucyjnie chronionych, a zwłaszcza zasady równości. W takim stanie rzeczy stwierdzić należy, że ustawodawca, mimo iż rzeczywiście ograniczył pewne uprawnienia, to jednak nie naruszył przez to ani art. 2, ani też art. 12 Konstytucji Rzeczpospolitej Polskiej z dnia 2 kwietnia 1997 roku (Dz.U. 1997, nr 78, poz. 483 ze zm., dalej: Konstytucja), które muszą być rozpatrywane w perspektywie innych wartości konstytucyjnych.

W związku z tym należy podzielić poglądy wyrażone w przywołanych orzeczeniach Trybunału Konstytucyjnego i Sądu Najwyższego, albowiem dotyczyły one rozwiązań przewidujących wygaszanie stosunków pracy w akceptowalnych uwarunkowaniach, to jest dotyczących ważnych zmian związanych $\mathrm{z}$ funkcjonowaniem sfery administracji publicznej poddanej istotnym przekształceniom - także w zakresie zatrudniania pracowników - z powodu zmian ustrojowych państwa, które można nazwać przełomowymi. Powyższe zmiany były związane ze skomplikowanymi działaniami natury organizacyjnej i finansowej w związku z reformą administracji publicznej i były oparte na domniemaniu istnienia ważnego interesu publicznego leżącego u podstaw wprowadzonych rozwiązań prawnych. Oznacza to, że nie każda reorganizacja w sektorze publicznym jest na tyle doniosła, aby uzasadniać posługiwanie się konstrukcją wygaszania stosunków pracy.

\section{Utworzenie Krajowego Ośrodka Wsparcia Rolnictwa jako przykład zmian strukturalnych $\mathbf{w}$ administracji publicznej}

Odnosząc się do bieżącego stanu prawnego, problematyka wygaszania stosunków pracy pojawiła się w związku z powołaniem w dniu 1 września 2017 roku Krajowego Ośrodka Wsparcia Rolnictwa (dalej: KOWR). Zgodnie z art. 45 ust. 1 ustawy z dnia 10 lutego 2017 roku - Przepisy wprowadzające ustawę o Krajowym Ośrodku Wsparcia Rolnictwa (Dz.U. 2017, poz. 624, dalej: PwKOWR) dnia 31 sierpnia 2017 roku nastąpiło zniesienie Agencji Rynku Rolnego (dalej: ARR) i Agencji Nieruchomości Rolnych (dalej: ANR). Zmiany te zostały uzupełnione o zastrzeżenie, że KOWR dnia 1 września 2017 roku z mocy prawa wstępuje w ogół praw i obowiązków znoszonej ANR. W uzasadnieniu do uchwały z 14 czerwca 2019 roku (III CZP 4/19, LEX nr 2685428) Sąd Najwyższy wskazał, że w zakresie zastosowania art. 46 ust. 1 PwKOWR doszło do sukcesji uniwersalnej KOWR po zlikwidowanej ANR (sukcesja mortis causa).

Regulacja art. 51 ust. 7 ustawy o Krajowym Ośrodku Wsparcia Rolnictwa z dnia 10 lutego 2017 roku (Dz.U. 2020, poz. 481 tekst jedn.) wprowadziła wygaśnięcie stosunków pracy pracowników w niej wskazanych z woli ustawodawcy w dniu 31 sierpnia 
2017 roku, chyba że przed tym dniem nowy pracodawca zaproponował tym pracownikom nowe warunki pracy lub płacy na dalszy okres. Należy zwrócić uwagę na to, że co do woli i treści tych propozycji pracodawca nie został skrępowany żadnymi wymaganiami. Ustawodawca bowiem ani nie przewidział swoistych wymagań dotyczących złożenia pracownikom propozycji nowych warunków pracy i płacy, ani nie odesłał do odpowiedniego stosowania przepisów o wypowiedzeniu zmieniającym, to jest do art. 42 w zw. z art. 45 k.p. Oznacza to, po pierwsze, możliwość, a nie konieczność złożenia przez nowego pracodawcę propozycji zatrudnienia, a po wtóre - że skuteczność propozycji pracodawcy nie zależy od jej zasadności w rozumieniu art. $45 \$ 1$ k.p. Uchwalenie ustawy powodującej wygaśnięcie stosunków pracy w takim trybie (a więc de facto utratę pracy) przez pracowników, poza jakąkolwiek kontrolą, rodzi obowiązek oceny nowej regulacji prawnej także pod względem jej zgodności z Konstytucją, a zwłaszcza z jej art. 24.

Na podstawie art. 51 ustawy PwKOWR prezes ARR oraz prezes ANR przekazali pelnomocnikowi ds. utworzenia KOWR (dalej: pełnomocnik) imienne wykazy pracowników wraz z podaniem ich stanowisk pracy, warunków zatrudnienia oraz posiadanych kwalifikacji i stażu pracy. Dawało to podstawy do uznania, że dobór pracowników do kontynuowania stosunku pracy z zasady miał być oparty na dotychczasowym przebiegu zatrudnienia, stażu pracy i posiadanych kwalifikacjach. Pełnomocnik proponował na piśmie zatrudnienie w KOWR, określając warunki pracy i płacy, a pracownicy składali oświadczenie o przyjęciu albo odmowie przyjęcia zaproponowanych warunków zatrudnienia. Ci pierwsi stali się dnia 1 września 2017 roku pracownikami KOWR. Dotychczasowe stosunki pracy pracowników ANR i ARR wygasły w dniu 31 sierpnia 2017 roku w przypadku złożenia oświadczenia o odmowie przyjęcia zaproponowanych warunków zatrudnienia, w przypadku niezłożenia w terminie oświadczenia oraz jeżeli nie zostało im zaproponowane zatrudnienie w nowo utworzonym KOWR.

Sens prawidłowego zastosowania tej instytucji sprowadza się do ustalenia, czy pracownikom znane były okoliczności, które spowodowały, że nie otrzymali propozycji zatrudnienia po 31 sierpnia 2017 roku i ich stosunki pracy wygasły, to jest: czy decyzja prowadząca w istocie do redukcji miejsc pracy była oparta na obiektywnych i merytorycznych kryteriach. Podkreślić należy, że skoro propozycja zatrudnienia miała się pojawić jedynie w odniesieniu do niektórych pracowników, i to ze strony reprezentanta podmiotu zatrudniającego, sytuacja ta przypomina dobór pracowników do zwolnienia właściwy dla rozwiązywania stosunków pracy, w tym w ramach zwolnień grupowych (dobór pozytywny i negatywny). Powyższa analiza pozwala na wyprowadzenie wniosku, że o prawidłowym zastosowaniu instytucji wygaśnięcia stosunku pracy można by mówić dopiero wówczas, gdyby pracodawca w sposób prawidłowy wypełnił nakazaną ustawowo procedurę przedstawiania pracownikom propozycji zatrudnienia. Jeżeli o wyborze do ustania zatrudnienia decyduje osoba reprezentująca interesy podmiotu zatrudniającego, to pozostawienie jej nieskrępowanej swobody stanowi podstawę do normatywnego usankcjonowania przyzwolenia na praktyki nierównościowe i dyskryminacyjne. Wprowadzenie wygaśnięcia stosunków pracy z mocy ustawy jest oczywiście dopuszczalne, jednakże w sytuacjach szczególnych, uzasadnionych zmianami ustrojowymi państwa. 
Likwidacja dwóch agencji rolnych i utworzenie w ich miejsce jednej nie stanowi takiej doniosłej zmiany ustrojowej państwa, zwłaszcza gdy nowo powołana jednostka zyskała zadania i kompetencje zbliżone do poprzednich. W takich uwarunkowaniach pracownik nie może zostać pozbawiony ochrony prawnej polegającej na sądowej kontroli tego, którym pracownikom zaproponowano dalsze zatrudnienie, a którym nie.

\section{Konstytucyjna ocena rozwiązań prawnych związanych z powołaniem Krajowego Ośrodka Wsparcia Rolnictwa}

Podkreślić należy, że przepisy obowiązującej Konstytucji oraz innych ustaw nie gwarantują nienaruszalności zatrudnienia. Konstytucja zwraca jedynie uwagę (art. 65 ust. 1), że swobodę zatrudnienia i miejsca pracy mogą ograniczać jedynie ustawy. Ze względu na potrzebę zmian strukturalnych w Polsce (w tym wypadku zmian ustroju administracji publicznej) uzasadnione może być ograniczenie praw jednostki, w tym też trwałości stosunku pracy, ze względu na interes publiczny czy dobro wspólne. Przepisy różnych ustaw chronią trwałość stosunku pracy przed dowolnością jego rozwiązania ze strony pracodawcy, a nie ustawodawcy. Postanowienia konstytucyjne powinny chronić i chronią także przed dowolnością ustawodawcy.

Prezentuję pogląd, że mechanizm wprowadzony w art. 51 ust. 7 ustawy o KOWR narusza przepisy art. $2 \mathrm{i}$ art. $24 \mathrm{w}$ zw. $\mathrm{z}$ art. 65 Konstytucji. Zgodnie z art. 24 Konstytucji: „Praca znajduje się pod ochroną Rzeczypospolitej Polskiej. Państwo sprawuje nadzór nad warunkami wykonywania pracy". Przytoczony przepis jest zaliczany do podstawowych zasad ustroju społeczno-gospodarczego państwa, stanowiąc dopełnienie postanowień zawartych w art. 20-23. Przepis art. 24 Konstytucji nakłada na państwo nakaz wydawania przepisów ochronnych wobec osób pracujących, w tym wobec pracowników, stanowi wytyczną legislacyjną dla ustawodawstwa pracy w zakresie ochrony pracy. W literaturze wskazuje się, że jest podstawą uzasadniającą byt ustawodawstwa pracy, którego celem jest wsparcie strony z reguły ekonomicznie słabszej, jaką jest pracownik, stanowi przy tym o obowiązku państwa do kreowania ustawodawstwa pracy przede wszystkim w kontekście rozwoju praw człowieka (Safjan, Bosek 2016; zob. wyrok Trybunału Konstytucyjnego z dnia 4 października 2005 roku, K 36/03, OTK-A 2005, nr 9, poz. 98). Aksjologicznego uzasadnienia dla nadawania pracy szczególnej rangi należy upatrywać $\mathrm{w}$ dwóch przesłankach. Po pierwsze praca stanowi istotne dobro publiczne (wartość) i jedną z głównych podstaw funkcjonowania gospodarki i jej rozwoju. Po drugie, z punktu widzenia jednostki ludzkiej, praca stanowi źródło godności człowieka oraz typową podstawę utrzymania dla większości obywateli. Ochrona pracy to - w tym wymiarze - całokształt instrumentów prawnych, politycznych i faktycznych osłabiających negatywne skutki, jakie niesie ze sobą dla pracownika silniejsza ekonomicznie pozycja pracodawcy. Ingerencja ta jawi się jako działanie niezbędne - sprzyjające zapewnieniu równowagi uczestników procesu pracy. Podkreśla się przy tym, że rola państwa powinna być w tym zakresie defensywna, czyli zapewniać ochronę pracy, a nie 
ofensywna, to jest przejawiać się w aktywnym i szerokim kształtowaniu warunków jej wykonywania. Ochrona pracy wskazana w tym postanowieniu obejmuje ogół środków i działań podejmowanych przez władze publiczne w celu zapewnienia poszanowania pracy i przyjmowania rozwiązań prawnych czyniących z niej podstawę egzystencji człowieka, w tym zapewnienia trwałości stosunku pracy. Konkretyzacja tych założeń jest zawarta w dalszych normach konstytucyjnych, w tym w art. 59, 65 i 66 Konstytucji. Nic nie stoi na przeszkodzie, aby z tej abstrakcyjnej zasady wydobywać konkretne treści prawne, co jest zadaniem doktryny i orzecznictwa (Liszcz 1997, s. 76 i n.; Bury, Dral 2014, s. 233 i n.). W ocenie Trybunału Konstytucyjnego istnieje możliwość uznania, że art. 24 Konstytucji może stanowić, w powiązaniu z innymi przepisami Konstytucji, wzorzec badania konstytucyjności określonych przepisów prawa pracy (zob. wyroki Trybunału Konstytucyjnego: $z$ dnia 29 kwietnia 2003 roku, SK 24/02, OTK-A 2003, nr 4, poz. 33; z dnia 7 października 2004 roku, II PK 29/04, OSNP 2005, nr 7, poz. 97; z dnia 24 października 2006 roku, SK 41/05, OTK-A 2006, nr 6, poz. 126). Idea solidaryzmu społecznego realizowana jest z zastosowaniem zasady subsydiarności, według której państwo stanowi ostatni podmiot zobowiązany do udzielenia wsparcia. Podstawowym obowiązkiem państwa jest zaś prowadzenie polityki gospodarczej umożliwiającej obywatelom zarobkowanie przez własną pracę oraz wprowadzenie rozwiązań prawnych chroniących przed nieuzasadnionym pozbawieniem pracownika możliwości tego zarobkowania (ochrona przed niezgodnymi z prawem bądź nieuzasadnionymi działaniami pracodawców). Tworzenie warunków do zachowania miejsc pracy stanowi element realizacji obowiązku ochrony przewidzianej w art. 24 Konstytucji. Argumentacja ta nie stanowi zresztą żadnego novum. Ocena działań ustawodawcy (który na skalę masową posługuje się „wygaszaniem” stosunków pracy) powszechnie i jednoznacznie oceniana jest krytycznie (Szewczyk 2018, s. 20 i n.; Świątkowski 2018, s. 9; Płażek 2019, s. 24 i n.). Zgodnie wskazuje się, że tego rodzaju praktyka jest niezgodna $\mathrm{z}$ art. 24, 30, 32 i 60 Konstytucji, a „wygaśnięcie” mające opisane cechy może być uznane za mające charakter pozorny - stanowiące $\mathrm{w}$ istocie rozwiązanie stosunku pracy. Podnosi się również, że w sytuacji gdy wybór pracownika, z którym umowa o pracę ma trwać, nie został obwarowany żadnymi obiektywnymi kryteriami, nie może być mowy o efektywnym zapewnieniu zasady równego traktowania i niedyskryminacji.

\section{Sądowe dochodzenie roszczeń w przypadku niezgodnego z prawem wygaśnięcia stosunku pracy}

Niezgodne z prawem, w tym dyskryminujące albo naruszające zasadę równego traktowania, niezaproponowanie pracownikowi dalszego zatrudnienia otwiera po jego stronie prawo do dochodzenia roszczeń z art. $56 \$ 1$ k.p., a na sąd nakłada powinność dokonywania wykładni przepisów w kierunku eliminującym przejawy nierównego traktowania (dyskryminacji). „Naruszenie przepisów”, o którym mowa w art. 67 k.p., statuujące prawo pracownika do roszczeń rozciągnięte zostało także na przepisy szczególne 
(pozakodeksowe; zob. Baran 2018, s. 494-495). Znaczy to tyle, że pracownikowi, także w przypadkach „pozakodeksowego" wygaśnięcia umowy o pracę powodowanych reorganizacjami u pracodawców sektora publicznego, w których $\mathrm{z}$ reguły przejawia się element woli jednej ze stron stosunku pracy co do jego niekontynuowania, przysługuje droga sądowa. Jeżeli bowiem „wygaśnięcie” zostanie uznane za upodobnione do rozwiązania więzi pracowniczej, to per analogiam właściwe wydaje się posiłkowanie zbieżnymi modelami ochronnymi, których niespełnienie skutkuje prawem do roszczeń $z$ art. 56 $\$ 1$ k.p. w związku z art. 67 zd. 2 k.p.

W tym świetle nie ulega wątpliwości, że niezaproponowanie określonym pracownikom propozycji zatrudnienia jest zachowaniem (nieczynieniem) nakierowanym na ustanie stosunku pracy. Sąd pracy w takich uwarunkowaniach może badać nie tylko to, czy stwierdzenie wygaśnięcia umowy o pracę przez pracodawcę nie naruszało przepisów prawa, ale także - a może przede wszystkim - okoliczności niezaproponowania pracownikowi warunków pracy i płacy na dalszy okres. Może też dokonywać oceny w kontekście zasad współżycia społecznego (por. wyrok Sądu Najwyższego z dnia 24 września 2009 roku, II PK 58/09, OSNP 2011, nr 9-10, poz. 124).

Konkludując, pracownik, któremu nie zaproponowano zatrudnienia, ma prawo dochodzić przed sądem pracy roszczeń za niezgodne z prawem wygaśnięcie stosunku pracy, a przesłanką tego roszczenia jest nie tylko formalne nieziszczenie się okoliczności warunkującej wygaśnięcie zobowiązania pracowniczego, ale również to, że niezaproponowanie mu zatrudnienia nie było podyktowane motywem sprzecznym z zakazami z art. 112 i 113 k.p.

\section{Problematyka wygaśnięcia stosunku pracy w sektorze publicznym w ostatnim orzecznictwie Sądu Najwyższego}

W wyroku z dnia 26 września 2019 roku (III PK 126/18, LEX nr 2729826) Sąd Najwyższy wskazał, że z konstrukcyjnego punktu widzenia wygaśnięcie umowy o pracę zachodzi tylko wówczas, gdy następuje wskutek zdarzenia prawnego innego niż czynność prawna. W ustawie PwKOWR owym zdarzeniem jest „niezaproponowanie zatrudnienia”. Zostało ono przeciwstawione czynności prawnej, jaką jest „zaproponowanie zatrudnienia”. Zależność ta w oczywisty sposób kłóci się z formułą wygaśnięcia stosunku pracy. Skoro wygaśnięcie nie może nastąpić na skutek czynności prawnej (bo wówczas należałoby je zakwalifikować jako rozwiązanie zatrudnienia), to logiczne jest, że jego zaistnienie nie może być uzależniane od dokonania takiej czynności. Prowadzi to do wniosku, że ustawodawca w art. 51 ust. 7 pkt 3 PwKOWR posłużył się mechanizmem, który żadną miarą nie ma się do jej logiczno-formalnego wzorca. Sąd Najwyższy, analizując procedurę dotyczącą utworzenia KOWR, wyraził zapatrywanie, że możliwe jest rozważanie, czy przewidziane w wyżej wymienionych przepisach „wygaśnięcie” nie stanowiło w istocie zakamuflowanego rozwiązania umowy o pracę. Omawiane „wygaśnięcie” stosunku pracy, mimo że z nazwy nawiązuje do instytucji znanej w prawie pracy, z charakteru 
nie mieści się w jej ramach. Można wręcz stwierdzić, że przypisane mu cechy upodabniają je do modelu rozwiązania stosunku pracy.

\section{Podsumowanie}

Nieprawidłowe posługiwanie się przez ustawodawcę mechanizmem wygaszania stosunków pracy przekłada się wprost na stopień ochrony i stabilizacji zatrudnienia pracowników. Jak już wskazywano, mieszczące się w kanonie prawniczym spojrzenie, że skoro ustawodawca przewidział skutek wygaśnięcia stosunku pracy, to kwestia ta nie podlega interpretacji, może prowadzić do niesprawiedliwych, wręcz krzywdzących następstw. Widać to szczególnie w sytuacji, gdy ustawodawca posługuje się atypowym wygaśnięciem stosunku pracy, którego ostrze wymierzone jest w pracownika, co polega między innymi na powierzeniu wyboru osób do ustania zatrudnienia (względnie jego kontynuacji) osobie reprezentującej interesy podmiotu zatrudniającego, której nieskrępowana swoboda w tym względzie stanowi podstawę do normatywnego usankcjonowania przyzwolenia na praktyki nierównościowe i dyskryminacyjne (z uzasadnienia przytaczanego wyroku Sądu Najwyższego z dnia 26 września 2019 roku). Zagrożeniem jest również sama konstrukcja, która może zostać zastosowana mimo tego, że właściwszą drogą byłoby rozwiązywanie z pracownikami stosunków pracy wraz z towarzyszącymi temu trybowi mechanizmami ochronnymi.

Idea solidaryzmu społecznego oznacza, że podstawowym obowiązkiem państwa jest prowadzenie polityki gospodarczej umożliwiającej obywatelom zarobkowanie przez własną pracę oraz wprowadzenie rozwiązań prawnych chroniących przed nieuzasadnionym pozbawieniem możliwości tego zarobkowania. Powstaje jednak pytanie, jak należy zachować się w sytuacji, gdy państwo nie wypełniło w sposób właściwy tego zadania. Z pewnością taki stan otwiera prawo do sądowego dochodzenia roszczeń. Może również pojawić się konieczność odchodzenia od wykładni językowej, mimo jednoznaczności brzmienia przepisów, jeżeli dosłowne ich brzmienie prowadzi do niesprawiedliwych lub irracjonalnych konsekwencji, w istocie, kiedy przemawiają za tym szczególnie ważne racje prawne, społeczne lub moralne. W konsekwencji taki sposób wykładni ma sprzyjać poszanowaniu pracy i przyjmowaniu rozwiązań prawnych czyniących z niej podstawę egzystencji człowieka, zapewnieniu trwałości stosunku pracy oraz bezpiecznych warunków jej wykonywania, do tego ochrony świadczeń związanych z pracą, a także zapobieganiu bezrobociu. Ma osłabiać ryzyko związane z nierównowagą, jaka występuje między stronami stosunku pracy.

Na koniec wypada przypomnieć, że w jednym z orzeczeń Trybunał Konstytucyjny (wyrok z dnia 24 października 2017 roku, K 1/17, OTK-A 2017, poz. 79) wyraził zapatrywanie, że ograniczenie bezpieczeństwa prawnego i pewności prawa $\mathrm{z}$ powodu ingerencji w stosunki pracownicze powinno się dokonywać $z$ poszanowaniem niezbędnych gwarancji bezpieczeństwa prawnego osób, których zaskarżone regulacje dotyczą, oraz z poszanowaniem gwarancji, które wykluczają arbitralność decydentów i nadmierną dolegliwość ograniczeń. 


\section{Bibliografia}

Baran K.W. (2018) Kodeks pracy. Komentarz, Warszawa.

Bury B., Dral A. (2014) Zasada ochrony pracy w Konstytucji RP, „Przegląd Prawa Konstytucyjnego", nr 3.

Dral A. (2009) Powszechna ochrona trwałości stosunku pracy, Warszawa.

Hajn Z. (1994) Przejście zakładu pracy na nowego pracodawcę a zasada wolności pracy, „Praca i Zabezpieczenie Społeczne", nr 5.

Hajn Z. (1996) Nowa regulacja przejścia zakładu pracy na innego pracodawce, „Praca i Zabezpieczenie Społeczne", nr 10.

Hofmańska E. (2015) Zbieg przyczyn ustania stosunku pracy, „Monitor Prawa Pracy”, nr 5.

Jończyk J. (1984) Prawo pracy, Warszawa.

Liszcz T. (1997) Przyszła Konstytucja Rzeczypospolitej Polskiej a prawo pracy, „Annales UMCS”, vol. 44, sectio G.

Mitrus L. (1998) Przejęcie zakładu pracy przez nowego pracodawcę w prawie Wspólnoty Europejskiej, „Praca i Zabezpieczenie Społeczne”, nr 2.

Pisarczyk Ł. (2007) Przejście zakładu pracy lub jego części na nowego pracodawcę-wybrane problemy, „Praca i Zabezpieczenie Społeczne”, nr 5.

Płażek S. (2019) Wygaśnięcie stosunków pracy z mocy prawa w administracji publicznej, „Praca i Zabezpieczenie Społeczne", nr 2.

Safjan M., Bosek L. (2016) (red.) Konstytucja RP, t. 1: Komentarz do art. 1-86, Kraków.

Sanetra W. (2011) [w:] J. Iwulski, W. Sanetra, Kodeks pracy. Komentarz, Warszawa.

Sobczyk A. (2015) (red.) Kodeks pracy. Komentarz, Warszawa.

Stelina J. (2015) Ewolucja kodeksowej regulacji wygaśnięcia stosunku pracy [w:] A. Kosut, W. Perdeus (red.), Przemiany prawa pracy - od kodyfikacji do współczesności. Księga Jubileuszowa dedykowana Profesor Teresie Liszcz, Lublin.

Szewczyk H. (2018) Podstawowe problemy reformy zatrudnienia członków korpusu służby cywilnej, „Praca i Zabezpieczenie Społeczne”, nr 4.

Świątkowski A. (2018) Pozakodeksowe przypadki wygaśnięcia stosunku pracy, „Palestra”, nr 3.

Tomanek A. (2002) Przejście zakładu pracy na innego pracodawcę, Warszawa.

Witoszko W. (2016) Przyczyny wygaśnięcia stosunku pracy w powszechnym i szczególnym prawie pracy [w:] L. Florek (red.), Powszechne a szczególne prawo pracy, Warszawa.

\section{Orzecznictwo}

Wyrok Trybunału Konstytucyjnego z dnia 13 marca 2000 roku, K 1/99, OTK 2000, nr 2, poz. 59. Wyrok Sądu Najwyższego z dnia 24 maja 2001 roku, I PKN 399/00, OSNP 2003, nr 6, poz. 143. Uchwała Sądu Najwyższego z dnia 18 grudnia 2001 roku, III ZP 25/01, OSNP 2002, nr 13, poz. 301.

Postanowienie Sądu Najwyższego z dnia 4 października 2002 roku, I PK 31/02, LEX nr 1170570.

Wyrok Trybunału Konstytucyjnego z dnia 29 kwietnia 2003 roku, SK 24/02, OTK-A 2003, nr 4, poz. 33. 
Wyrok Sądu Najwyższego z dnia 27 stycznia 2004 roku, I PK 244/03, LEX nr 2449630.

Wyrok Sądu Najwyższego z dnia 7 października 2004 roku, II PK 29/04, OSNP 2005, nr 7, poz. 97.

Wyrok Trybunału Konstytucyjnego z dnia 4 października 2005 roku, K 36/03, OTK-A 2005, nr 9, poz. 98.

Wyrok Trybunału Konstytucyjnego z dnia 24 października 2006 roku, SK 41/05, OTK-A 2006, nr 6, poz. 126.

Wyrok Sądu Najwyższego z dnia 27 lipca 2007 roku, I PK 333/06, LEX nr 470022.

Wyrok Sądu Najwyższego z dnia 24 września 2009 roku, II PK 58/09, OSNP 2011, nr 9-10, poz. 124.

Wyrok Sądu Najwyższego z dnia 7 kwietnia 2010 roku, II UK 357/09, OSNP 2011, nr 19-20, poz. 258.

Wyrok Trybunału Konstytucyjnego z dnia 24 października 2017 roku, K 1/17, OTK-A 2017, poz. 79.

Uchwała Sądu Najwyższego z dnia 14 czerwca 2019 roku, III CZP 4/19, LEX nr 2685428.

Wyrok Sądu Najwyższego z dnia 26 września 2019 roku, III PK 126/18, LEX nr 2729826.

\section{Akty prawne}

Konstytucja Rzeczypospolitej Polskiej z dnia 2 kwietnia 1997 roku, Dz.U. 1997, nr 78, poz. 483 ze zm.

Ustawa z dnia 26 czerwca 1974 roku - Kodeks pracy, Dz.U. 2019, poz. 1040 tekst jedn. ze zm.

Ustawa z dnia 22 marca 1990 roku o pracownikach samorządowych, Dz.U. 2001 nr 142 poz. 1593 tekst jedn. ze zm.

Ustawa z dnia 13 października 1998 roku - Przepisy wprowadzające ustawy reformujące administrację publiczną, Dz.U. 1998, nr 133, poz. 872.

Ustawa z dnia 13 marca 2003 roku o szczególnych zasadach rozwiązywania z pracownikami stosunków pracy z przyczyn niedotyczących pracowników, Dz.U. 2018, poz. 1969 tekst jedn. ze zm.

Ustawa z dnia 10 lutego 2017 roku o Krajowym Ośrodku Wsparcia Rolnictwa, Dz.U. 2020, poz. 481 tekst jedn.

Ustawa z dnia 10 lutego 2017 roku - Przepisy wprowadzające ustawę o Krajowym Ośrodku Wsparcia Rolnictwa, Dz.U. 2017, poz. 624. 